\title{
Zola journaliste, articles et chroniques, choisis et présentés par Adeline Wrona
}

\author{
Ida Merello
}

\section{(2) OpenEdition}

\section{Journals}

\section{Edizione digitale}

URL: http://journals.openedition.org/studifrancesi/5727

DOI: 10.4000/studifrancesi.5727

ISSN: 2421-5856

\section{Editore}

Rosenberg \& Sellier

\section{Edizione cartacea}

Data di pubblicazione: 1 septembre 2011

Paginazione: 447-448

ISSN: 0039-2944

\section{Notizia bibliografica digitale}

Ida Merello, «Zola journaliste, articles et chroniques, choisis et présentés par adeline Wrona», Studi

Francesi [Online], 164 (LV | II) | 2011, online dal 30 novembre 2015, consultato il 08 janvier 2021. URL: http://journals.openedition.org/studifrancesi/5727 ; DOI: https://doi.org/10.4000/studifrancesi.5727

Questo documento è stato generato automaticamente il 8 janvier 2021.

\section{cc) (1) 8}

Studi Francesi è distribuita con Licenza Creative Commons Attribuzione - Non commerciale - Non opere derivate 4.0 Internazionale. 


\title{
Zola journaliste, articles et chroniques, choisis et présentés par Adeline Wrona
}

\author{
Ida Merello
}

\section{NOTIZIA}

Zola journaliste, articles et chroniques, choisis et présentés par Adeline WRONA, Paris, Garnier Flammarion 2011, 387 pp.

1 Adeline WRONA prosegue l'iniziativa inaugurata dalle edizioni GF con i Journaux di Marivaux, sulla base del rinnovato interesse critico per i rapporti tra stampa e letteratura. Ecco così la presentazione di Zola giornalista, che abbraccia circa quarant'anni, dal 1864 al 1898. La curatrice mostra i primi passi della carriera dello scrittore, quando si limitava per la Hachette a una sintesi pubblicitaria delle opere altrui, quindi l'affermazione della carriera giornalistica, intrapresa sotto diversi pseudonimi e fonte principale del suo sostentamento per almeno dieci anni, infine gli articoli di cronaca parlamentare. Ma è col momento della piena affermazione letteraria che Zola sfrutta la posizione conquistata, per creare serie e rubriche a difesa delle sue teorie. L'antologia si conclude con la campagna su «Le Figaro» contro i Repubblicani che hanno tradito i loro valori, con il famoso «J'accuse» e con l'altrettanto veemente articolo a difesa del padre di cui si tentava di infangare la memoria. 